\title{
Research on the sustainable use of Zhenjiang's industrial building heritage under the green concept
}

\author{
Hongwei $\mathrm{Si}^{1}$, Weiwei Qin ${ }^{1 *}$ \\ ${ }^{1}$ Institute of Architecture and Environment Art, Shanghai Urban Construction Vocational College, Shanghai, 201415, China
}

\begin{abstract}
The industrial architectural heritage of Zhenjiang has unrepeatable technological and cultural art values. This paper fully understands and scientifically evaluates the characteristics and values of industrial architectural heritage, analyzes different sustainable utilization strategies for industrial architectural heritage under the guidance of green concept, and gives corresponding design and measures for conservation and utilization of industrial architectural heritage.
\end{abstract}

\section{Modernization of Zhenjiang Industry}

The modern period of Zhenjiang began in 1861 with the opening of the port and the establishment of a concession area, and ended in 1949 with the founding of the People's Republic of China. After the opening of the port, foreign investors came to open foreign companies, domestic merchants from the north and south to trade, and gradually

formed the Jiang Guang industry (North and South goods), Jiang silk industry (Jingjiang silk), timber industry, silk cloth industry, money industry, foreign, government-run, private ship transport industry quickly emerged, modern industry began to found, from 1895 to 1911, silk, flour, electric lamps, oil, paper and other more than 10 factories (Table 1) [1], At the same time, the emergence and development of the railroad promoted the prosperity of urban industry, thus starting the modernization process of Zhenjiang.

Table1. The factories in Zhenjiang from the late 19th century to the beginning of $20^{\text {th }}$ century

\begin{tabular}{|c|c|c|c|c|c|}
\hline Factory & $\begin{array}{l}\text { Era } \\
(\mathrm{AD})\end{array}$ & Location & Factory & Era $(\mathrm{AD})$ & Location \\
\hline Sijing Silk Factory & 1894 & $\begin{array}{l}\text { West Lotus } \\
\text { Pond }\end{array}$ & $\begin{array}{l}\text { Zhenjiang Yisheng Match } \\
\text { Factory }\end{array}$ & 1910 & \\
\hline Dallen Silk Factory & 1894 & Xijinfang & $\begin{array}{l}\text { Zhenjiang Dayuan Oil } \\
\text { Press Factory }\end{array}$ & 1913 & \\
\hline Yongli Silk Reeling Factory & 1895 & $\begin{array}{c}\text { East of } \\
\text { Jinshan River }\end{array}$ & $\begin{array}{l}\text { Zhenjiang Baochang } \\
\text { Machine Factory }\end{array}$ & 1913 & \\
\hline Dantou Dailian Silk Factory & 1895 & & $\begin{array}{l}\text { Zhenjiang Maochang } \\
\text { Machine Factory }\end{array}$ & 1913 & \\
\hline $\begin{array}{l}\text { Zhenjiang Zui Lun Silk } \\
\text { Factory }\end{array}$ & 1896 & & $\begin{array}{c}\text { Zhenjiang Ciyou Weaving } \\
\text { Factory }\end{array}$ & 1913 & \\
\hline Zhenjiang Heixing Flour Mill & 1903 & & $\begin{array}{c}\text { Zhenjiang Yicheng Flour } \\
\text { Mill }\end{array}$ & 1914 & $\begin{array}{l}\text { west of the } \\
\text { city }\end{array}$ \\
\hline $\begin{array}{c}\text { Zhenjiang Kaicheng Pen \& } \\
\text { Lead Can Factory }\end{array}$ & 1904 & & $\begin{array}{l}\text { Zhenjiang Fucheng Silk } \\
\text { Factory }\end{array}$ & 1916 & \\
\hline $\begin{array}{l}\text { Zhenjiang Dazhao Electric } \\
\text { Light Factory }\end{array}$ & 1905 & $\begin{array}{l}\text { East Lotus } \\
\text { Pond }\end{array}$ & $\begin{array}{l}\text { Zhenjiang Yuji Silk } \\
\text { Factory }\end{array}$ & 1916 & \\
\hline $\begin{array}{l}\text { Zhenjiang Tongmaoyong Egg } \\
\text { Factory }\end{array}$ & 1905 & & $\begin{array}{l}\text { Great China Match } \\
\text { Company }\end{array}$ & & \\
\hline $\begin{array}{c}\text { Zhenjiang Zhentai Oil Press } \\
\text { Factory }\end{array}$ & 1906 & & Yingchang Match Factory & 1920 & $\begin{array}{l}\text { west of the } \\
\text { city }\end{array}$ \\
\hline $\begin{array}{c}\text { Dantu Tailai Yuanji Machine } \\
\text { Flour Mill }\end{array}$ & 1907 & & Daxin Stone Powder Plant & 1936 & \\
\hline Zhenjiang Paper Mill & 1909 & & Alcohol plant & $1938-1945$ & \\
\hline $\begin{array}{l}\text { Zhenjiang Yuan Sheng Oil } \\
\text { Press Factory }\end{array}$ & 1909 & & & & \\
\hline
\end{tabular}

\footnotetext{
*Corresponding author's e-mail: qinweiwei@succ.edu.cn
} 


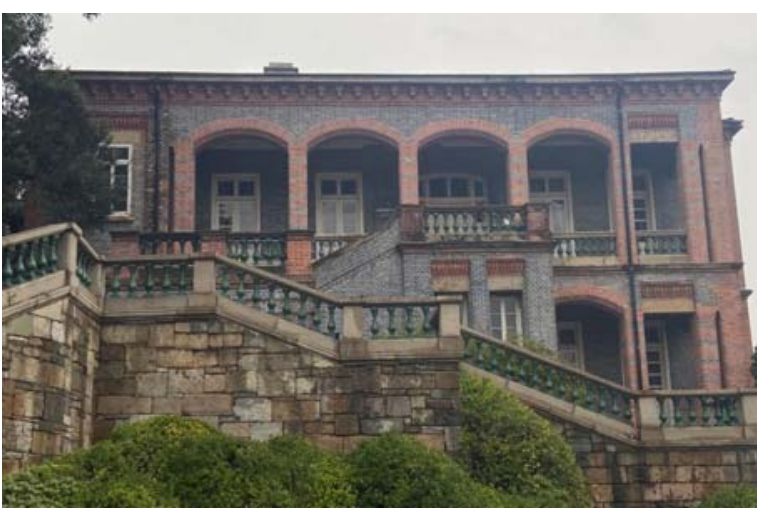

Figure 1. Zhenjiang U.S. Consulate

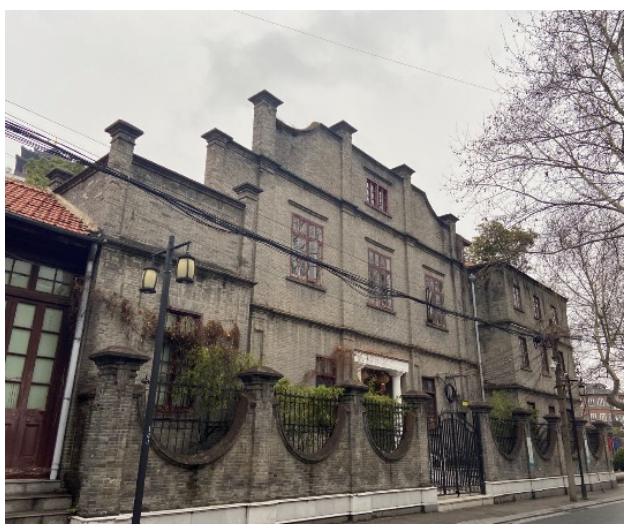

Figure 3.Zhenjiang Chamber of Commerce

\section{Characteristics and value of Zhenjiang's industrial architectural heritage}

In the process of modernization of Zhenjiang, a number of industrial buildings with remarkable characteristics have appeared. They have modern characteristics in artistic style, spatial form, modeling features, material structure, construction methods, etc., reflecting the modernization of Zhenjiang from one side, and have high historical, cultural and architectural art value [2]. In modern Zhenjiang, many European-style buildings and Republican buildings combining Chinese and Western styles were built, and there are many modern European-style buildings preserved, such as the British Consulate in Zhenjiang (Figure 1), the British Concession Works Bureau, Mobil Kerosene Company, Texaco Kerosene Company, the old post office (Figure 2), etc.; the Republican buildings are a combination of Chinese and Western architectural styles, such as the office building of Jiangsu Provincial Highway Bureau, Zhenjiang Chamber of Commerce (Figure 3), the old site of the Life Saving Society, the old site of Guangzhao Public Office, the official office of the Republic of Other buildings include the original office building of Zhenjiang Waterworks (Figure 4) [3], which is a series of industrial buildings of different ages, showing the road of industrialization of Zhenjiang to the world vividly.

With the establishment of the West Gate Railway Station and the small dock branch line and the rise of

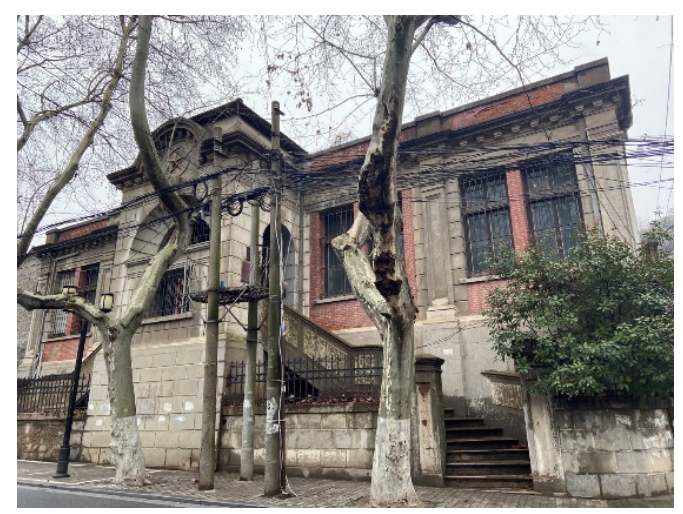

Figure 2. Zhenjiang Old Post Office

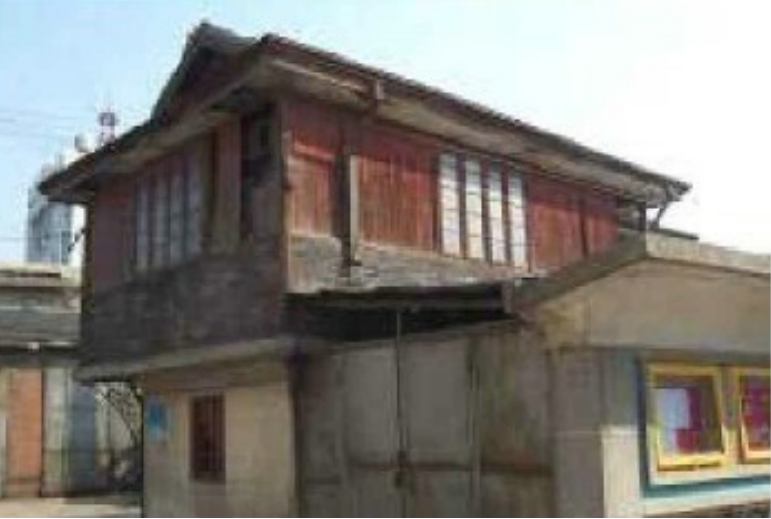

Figure 4. Office building of Zhenjiang Water Treatment Plant

railroad transportation, which led to the development of the modern industrial area in the west district, Zhenjiang's industrial architectural heritage is mostly distributed along the west railroad station, the Jinshan River generation, the riverside docks and both sides of the canal [4], reflecting the characteristics of industrial development in terms of spatial pattern, and also fully reflecting the close relationship between industrial development and the river network and water system in the past. The surviving industrial architectural heritage is rich in terms of building type, architectural age and stylistic features, including factory workshops and warehouses, chambers of commerce, docks, municipal facilities, etc. [5].

Zhenjiang's industrial architectural heritage has important historical and artistic values in modern architectural history. The buildings embody the characteristics of various styles and schools in the history of architectural art development in the modern Western colonial period, and have architectural historical research value, which gives people a strong sense of identity and spatial location. They also have an economic value, which is mainly reflected in the potential for reuse of their structures or spaces and the integrity of their current state of preservation. 


\section{Thinking about the current situation of
the architectural heritage of industrial \\ 3 Thinking about the current situation of
the architectural heritage of industrial buildings in Zhenjiang and the sustainability of conservation}

\subsection{Current status}

However, due to the destruction during the anti-Japanese war and the rapid development of urbanization, many modern buildings have been demolished, altered or abandoned due to the large-scale renewal of the old city, and only a few buildings are listed in the protection units (Table 2).

Table 2 Status of protection and utilization of industrial heritage in Zhenjiang

\begin{tabular}{|c|c|c|}
\hline Name & Level & Utilization Status \\
\hline $\begin{array}{c}\text { Former site of the British } \\
\text { Consulate }\end{array}$ & National level & Zhenjiang Museum Exhibition Hall \\
\hline $\begin{array}{c}\text { Former site of the U.S. } \\
\text { Consulate }\end{array}$ & National level & Zhenjiang Museum Exhibition Hall \\
\hline Customs Post Office & Municipal level & Zhenjiang Ethnic Culture Museum \\
\hline $\begin{array}{c}\text { Mobil Oceania } \\
\text { Former site of Mobil Fire Oil } \\
\text { Company }\end{array}$ & Municipal level & Zhenjiang Workers' Sanatorium \\
\hline $\begin{array}{c}\text { Asia Former site of Fire Oil } \\
\text { Company }\end{array}$ & Municipal level & Titanium dioxide plant office building \\
\hline $\begin{array}{c}\text { Former site of Texaco Kerosene } \\
\text { Company }\end{array}$ & Municipal level & Dismantled, to be moved and rebuilt \\
\hline $\begin{array}{c}\text { Zhenjiang Chamber of } \\
\text { Commerce }\end{array}$ & Municipal level & Zhenjiang City Chamber of Commerce \\
\hline Guangzhao Public Office & Municipal level & Public buildings \\
\hline Tax Division Public House \\
$\begin{array}{c}\text { First Firefighters' Association } \\
\text { Waterworks }\end{array}$ & Municipal level & Abandoned, to be restored to construction \\
\hline
\end{tabular}

In terms of preservation, very little industrial architectural heritage remains in the old city, while the industrial and storage remains along the Yangtze River, which depend on the wharves, and the industrial architectural remains located in the historical district in the west of the city have been partially preserved and reused due to their distance from the city center and their high architectural and artistic value (Table 2[6]).

\subsection{Thinking about the sustainability of conservation}

The recognition of industrial architectural heritage depends on value, and the first aim of conservation is to avoid destruction. Will the value be fully recognized? Is the missing one necessary to be restored? To what extent is restoration necessary? This is the second purpose of conservation - the question of utilization.

The preservation and sustainable development of Zhenjiang's industrial architectural heritage still has some problems so far, dealing with the relationship between preservation and development is not thorough, the enforcement of laws concerning industrial architectural heritage is limited; the cooperation between all levels, industries and local governments is not high; the promotion of large-scale restoration and repair makes the heritage lose its original originality, authenticity and uniqueness; the investment resources are limited and the potential of the masses is not played [7].

Some industrial buildings in Zhenjiang that are listed or not listed for protection have been converted into offices, commercial facilities or creative industrial parks. However, in the specific conversion projects, due to the lack of green concept and conservation planning guidance and historical building assessment, simple transformation methods are often used in the conversion, lack of excavation for the cultural connotation contained in the building, which has brought some impact on the architectural features and historical information [8]. For example, although the whole building of Mobil Kerosene Company has been preserved, the image of the building has been destroyed in the process of reuse of the building.

\section{Sustainable utilization strategy under the green concept}

With the support of the concept of sustainable development, there is a suitable strategy for the sustainable use and transformation of industrial buildings in Zhenjiang, which is the strategy of sustainable use of buildings under the green concept. This strategy requires today's industrial building sites in the utilization design process to ensure that the buildings can constantly demonstrate the characteristics and performance of pollution-free, low-energy, efficient, ecologically balanced and comfortable, to ensure that the geographical environment and supporting facilities of the building site are analyzed, and to use reasonable artificial technical means to ensure the health and comfort of the buildings [9], which is also the purpose of the green conservation concept. 


\subsection{Green planning for conservation and utilization}

Under the guidance of green concept, the reuse potential of Zhenjiang industrial building structure or space is first classified according to the degree of ease of use, and divided into industrial building sites with one or more ways of use, relatively easy to transform, and high possibility of reuse (such as Zhenjiang Chamber of Commerce, Mobil Oil Company office building, Zhenjiang General Post Office, the first fire-fighting club water plant office building, etc.); with one or more ways of use, and general difficulty of transformation, and general possibility of reuse (such as Danyang Yarn Factory office building, Danyang Yarn Factory sand turning room, Danyang Flour Factory warehouse, etc.). The transformation difficulty is general and the possibility of reuse is average (such as the office building of Danyang Yarn Factory, the sand turning room of Danyang Yarn Factory, the warehouse of Danyang Flour Factory, etc.). In view of the early and late construction time of industrial sites, different lot industries and different sizes, different conservation planning and design are adopted[10].

The first is to try the museum or exhibition hall model in the mode of conservation and utilization. The eastern foot of Yuntai Mountain in Zhenjiang is the area where the concession was set up after the opening of Zhenjiang, so a large number of relics related to the concession remain, such as the British and American Consulate, the Bureau of Public Works, the taxation department's public house, the Guangzhao public office, etc. Most of them have been converted into museums or exhibition halls. Now most of them have been converted into museums or exhibition halls, see Table 2. combined with buildings and structures to set up main museums, exhibition halls, showrooms, memorial halls, etc.; followed by alteration and functional conversion, gathering many small and medium-sized entrepreneurial enterprises; designed to become new office spaces, libraries, teaching buildings, industrial culture tourism and leisure centers, etc.; for example, the former administrative building of Danyang Yarn Factory can be considered to be converted into a library or office building, etc. The second is the green planning of the heritage and the surrounding natural environment. The design of vegetation structures in the planning and design is the most important, which is the basis for keeping soil and water, improving the environment and creating a proper historical atmosphere. The last is to carry out the green design of the industrial buildings in Zhenjiang and the surrounding traffic. The green traffic design should ensure its continuity and good landscape. Architectural heritage traffic should be connected with the surrounding traffic to jointly build a green urban transportation system, and local areas can be combined with the surrounding recreational resources and use needs of the location to form an independent system. Non-motorized paths and pedestrian paths in each city should be established in historic streets as a priority, and the two can be side by side. Non-motorized road surface material should be gravel or tar as much as possible, and motorized roads should be ensured to have a wide enough green belt whenever conditions allow [11].

\subsection{Sustainable utilization measures}

To improve the sustainable development of Zhenjiang's industrial architectural heritage, there are the following measures. First, materialism tells us that things are in, so I am in. Therefore, do heritage building archives, record authenticity, is the current protection of the imperative, this is the basis of sustainable use; second, in the first do building archives on the basis of digital information processing, the establishment of digital heritage database, such as the Dunhuang Cave Temple digital exhibition in general, the digitization of industrial architectural heritage is also an effective way to green protection of sustainable use; third, improve Zhenjiang public participation consciousness of preserving and developing industrial architectural heritage, so that the public understands that preserving and developing the value of architectural heritage is not only the responsibility of the state or everyone's responsibility, and at the same time, the utilization of architectural heritage should also be aimed at serving the public; fourth, harmoniously deal with the relationship between the protection of industrial architectural heritage in Zhenjiang and the development and construction of local urban planning and tourism resources development. It should not be biased and lost, but also moderate; fifth, the relevant government departments in Zhenjiang should strengthen the supervision and inspection of industrial architectural heritage preservation and sustainable development, information management, and protect the heritage according to the cultural heritage law to ensure the safety and sustainable development of Zhenjiang's industrial architectural heritage [12].

\section{Summary}

The preservation and sustainable use of Zhenjiang's industrial architectural heritage should explore a scientific management model and sustainable development path suitable for green urban development in ideas, methods and technologies. It is necessary to avoid the waste of urban resources, enrich the cultural heritage and connotation of the city, consciously abide by the World Heritage Convention, firmly establish the basic principles of scientific management, based on conservation and moderate development, protect Zhenjiang's industrial architectural heritage and provide vitality for the development of Zhenjiang's social economy.

\section{Acknowledgments}

This paper is supported by the first-class higher vocational (professional) construction project "first-class professional construction of cultural relics restoration and conservation" (project number: YZ-2019-A) and Shanghai Urban Construction Vocational College's 2020 schoollevel research project "research on the development pattern and regional characteristics of Han tombs in Ningzhen area "(Project No. cjky202010) jointly funded. 


\section{References}

1. Dai YH. (2006) The opening of Zhenjiang port and modern commercial changes. Jiangsu Business Theory, 5: 48-50. Liu J. (2012) A study on modern architectural forms and their evolution in Zhenjiang. Wuxi: Jiangnan University. 54.

2. Liu J. (2012) A study on modern architectural forms and their evolution in Zhenjiang. Wuxi: Jiangnan University. 1.

3. Zhu Q. (2007) "The Construction of Corridor for the Jiangnan Section of the Industrial Heritage of the Beijing-Hangzhou Grand Canal", Peking University PhD Dissertation. 101-110.

4. Liu J. (2012) A study on modern architectural forms and their evolution in Zhenjiang. Wuxi: Jiangnan University. 54.

5. Zhang S, Chen P. (2010) Conservation of industrial building heritage and development of creative parks in Shanghai - a survey, analysis and its reflection based on Hong Kou District. Journal of Architecture, 12: $12-16$.

6. Zhu Q. (2007) "The Construction of Corridor for the Jiangnan Section of the Industrial Heritage of the Beijing-Hangzhou Grand Canal", Peking University PhD Dissertation. 166.

7. Tao HC. (2019) Preserving and developing the value of architectural cultural heritage and sustainable development in Vietnam. Beauty and Times (Urban Edition), 7: 109-110.

8. Zhang S, Chen P. (2010) Conservation of industrial building heritage and development of creative parks in Shanghai - a survey, analysis and its reflection based on Hong Kou District. Journal of Architecture,12: 12-16.

9. Zhao H. (2020) Regeneration of industrial building heritage under the green concept. Urban Housing, $7: 131-132$.

10. Zhu Q, (2007)"Construction of the Corridor of the Jiangnan Section of the Industrial Heritage of the Beijing-Hangzhou Grand Canal", Peking University PhD Dissertation. 150-165.

11. Zhu Q, (2007)"Construction of the Corridor of the Jiangnan Section of the Industrial Heritage of the Beijing-Hangzhou Grand Canal", Peking University PhD Dissertation. 150-165.

12. Tao HC. (2019) Preserving and developing the value of architectural cultural heritage and sustainable development in Vietnam. Beauty and Times (Urban Edition), 7: 109-110. 